\title{
The Grand Design of Cooperative Roles in East Java to Support the Master Plan of the Acceleration and the Expansion of Indonesian Economy Development (MP3EI)
}

\author{
Puji Handayati
}

State University of Malang, Indonesia

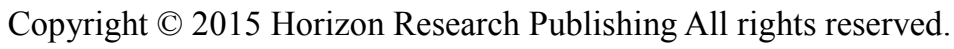

\begin{abstract}
The economy growth in East Java this time reaches to $7.22 \%$, it is the role of the Cooperative and the Micro, small and Medium Business (UMKM). This study aims to produce the mapping grand design of cooperative roles in East Java to support Master Plan of the Acceleration and the Expansion of Indonesian Economy Development (MP3EI) .This study is an exploration research by using the economy and spatial analysis in order to map the cooperative roles in supporting MP3EI achievement especially in East Java. The data used in this research are spatial and non-spatial data. The research result shows that the cooperative number recorded in Malang Region completely spread out in 33 districts as many as 1,095 units, however, the active cooperatives are as many as 629 units. Almost $81 \%$ of those are service cooperatives exactly they are credit cooperatives (KSP), consumer cooperatives are as many as $3 \%$ (21 cooperatives), and $13.5 \%$ are business cooperatives, and $2 \%$ are producer cooperatives. For Malang, from the field observation data result, which is done, we can get data that 700 cooperative data gotten from the Cooperative Service and UMKM, only 220 cooperatives are still active. From those of 220, all of them are credit cooperatives (service cooperatives); however, besides the cooperatives provide credit service, 42 cooperatives belong to consumer cooperatives. 2 cooperatives belong to producer cooperatives and 8 cooperative belong to business cooperatives (KSU). Suggestions for the research are: increasing the synergy among the related Services/Agencies (the Cooperative Service and UMKM, the industry service, the local government and the educational institution) to support the cooperative improvement in the regencies and in Malang, giving the early learning about the roles and functions of the cooperatives to support the national development and the usefulness for the people's economy movement, supplying and updating the database of the cooperative existence in the Cooperative Service and mikro, small and medium business .
\end{abstract}

Keywords Grand Design of Cooperative, Mapping , MP3EI

\section{Introduction}

The effort to open an access as widely as possible to the Indonesian society in the development and the synergizing development as the whole intent, the government makes a brave progress transformation in the form of economy acceleration and economy development expansion. With the vision of "Moving Indonesia to become a developed country and having the power of 12 biggest countries in 2025 through the high economy growth inclusively and continuously", government issues a project written on the draft entitled Master Plan of the Acceleration and the Expansion of Indonesian Economy Development (MP3EI) 2011 - 2025 passed with the President Regulation No. 32 2011, and it is based on the spirit of not business as usual, and involved all of the stakeholders.

This mega project states the implementation strategy by integrating 3 (three) main elements, namely: (1) developing the region economy potency in 6 (six) Indonesian Economy Corridors, namely: Sumatra Economy Corridor, Java Economy Corridor, Kalimantan Economy Corridor, Sulawesi Economy Corridor, Bali-Nusa Tenggara Economy Corridor, and Papua-Maluku Island Economy Corridor; (2) strengthening the national connectivity which is integrated locally and connected globally ( locally integrated and globally connected; (3) strengthening the Human Resource' and the national Science and Technology to support the main development program in every Economy Corridor. The third pillar (3) namely strengthening the human resource and the science and technology can be a way to increase the quality of the national product, therefore; the domestic product can compete with the foreign products and support our society to love our national products more. 
Table 1. The Cooperative Development in East Java

\begin{tabular}{|c|c|c|c|c|c|c|c|c|c|}
\hline \multirow{2}{*}{ Year } & Active & $\begin{array}{c}\text { Non } \\
\text { Active }\end{array}$ & Total & $\begin{array}{c}\text { members } \\
\text { (people) }\end{array}$ & $\begin{array}{c}\text { employee } \\
\text { (people) }\end{array}$ & $\begin{array}{c}\text { Own } \\
\text { Capital }\end{array}$ & $\begin{array}{c}\text { Outside } \\
\text { Capital }\end{array}$ & $\begin{array}{c}\text { Business } \\
\text { Volume }\end{array}$ & $\begin{array}{c}\text { Net } \\
\text { Income }\end{array}$ \\
\cline { 2 - 10 } & (unit) & (Unit) & (Unit) & Amount & Amount & (Rp. million & (Rp. million) & (Rp. million) & (Rp.million) \\
\hline 2005 & 12.282 & 4.893 & 17.175 & 4.805 .356 & 47.780 & $3.025 .549,49$ & $3.978 .219,87$ & $5.936 .339,03$ & $281.386,52$ \\
\hline 2006 & 13.201 & 4.095 & 17.296 & 4.612 .071 & 47.664 & $3.764 .873,66$ & $5.199 .695,13$ & $21.060 .197,23$ & $381.038,94$ \\
\hline 2007 & 13.891 & 4.027 & 17.918 & 5.002 .532 & 49.641 & $4.233 .613,98$ & $5.123 .337,21$ & $14.022 .084,02$ & $297.883,64$ \\
\hline 2008 & 14.669 & 3.987 & 18.656 & 5.057 .750 & 55.019 & $5.131 .558,35$ & $5.719 .319,52$ & $18.297 .965,35$ & $340.392,77$ \\
\hline 2009 & 15.674 & 3.722 & 19.396 & 5.107 .846 & 56.914 & $6.369 .654,53$ & $6.774 .368,06$ & $21.497 .790,08$ & $1.038 .011,45$ \\
\hline 2010 & 19,437 & 3,722 & 23,159 & $5,209,364$ & 57,584 & $6,992,096.20$ & $7,573,913.75$ & $11,458,626.36$ & $1,137,739.35$ \\
\hline
\end{tabular}

Source : Consolidation from some Reports of SKPD Service which covers KUKM, 2011

The data from the Cooperative Service and micro, small and medium business in East java province in $2004-2011$ showed that the more years, the average development of the cooperatives in east Java was promising. We can see the year of 2004, the percentage of the active cooperatives in East Java was 70. 34, while in 2005 it raised into $1.17 \%$. It means that the number development of the active cooperatives during $2004-2011$ only happened twice, in 2008 and in 2011 with decreasing $0.86 \%$ from 2007 until 2008 , while in the year of 2011 , the decreasing was $0.75 \%$ from 2010. However, it did not decrease the development. The biggest increasing percentage of the active cooperatives happened in 2010, it increased $6.23 \%$ from 2009.

From the data of the consolidation above, we can see that the cooperative development in East Java in both the active cooperative number and the business volume employee show the good results. The cooperative program and UMKM are able to decrease the poverty in East Java up to $2.83 \%$. Alternatively, we can say that it contributes $37 \%$ national poverty decreasing number. The important role of those cooperatives and UMKM is considered necessary to organize the Mapping Grand Design of the Cooperative Roles in East Java to support MP3EI.

The formulation of the research problem is "How to organize the Grand Design mapping of the Cooperative roles in East Java to support the MP3EI based on existed local Potency characteristics? The general objective of this research is to produce the Grand Design Mapping of the Cooperatives Role in east Java to support MP3EI.

\section{Methodology}

This is an exploration research. The objects of the research are the stakeholders related to the organization of the mapping grand design of the cooperative roles in East Java to support the achievement of Mega Project MP3EI such as the Local Government of East Java Province, the group of cooperative doers (the committee and the cooperative members are included), society, and related people. Two analysis used are economy (Matrix Strength Weaknesses - Opportunities - Threat (SWOT); they are important matching tool to help developing four strategy types, namely SO strategy (Strength-Opportunity), WO strategy (Weakness-Opportunity), ST strategy (Strength-Threat), and WT strategy (Weakness-Threat) and spatial for mapping the cooperative roles to support the achievement of MP3EI especially in East Java region.

Table 2. Cooperatives Per District in Malang Regent

\begin{tabular}{|c|c|c|c|c|}
\hline \multirow{2}{*}{ No. } & \multirow{2}{*}{ Name of District } & \multirow{2}{*}{ amount } & \multicolumn{2}{|c|}{ condition } \\
\hline & & & Active & Non Active \\
\hline 1 & Ampelgading & 18 & 16 & 2 \\
\hline 2 & Batur & 18 & 16 & 2 \\
\hline 3 & Bululawang & 38 & 27 & 11 \\
\hline 4 & Dampit & 27 & 15 & 12 \\
\hline 5 & Dau & 11 & 7 & 4 \\
\hline 6 & Donomulyo & 22 & 15 & 7 \\
\hline 7 & Gedangan & 14 & 10 & 4 \\
\hline 8 & Gondang legi & 50 & 27 & 23 \\
\hline 9 & Jabung & 22 & 17 & 5 \\
\hline 10 & Kalipare & 20 & 6 & 14 \\
\hline 11 & Karangploso & 25 & 20 & 5 \\
\hline 12 & Kasembon & 13 & 10 & 3 \\
\hline 13 & Kepanjen & 52 & 43 & 9 \\
\hline 14 & Kromengan & 13 & 5 & 8 \\
\hline 15 & Lawang & 44 & 30 & 14 \\
\hline 16 & Ngajum & 12 & 11 & 1 \\
\hline 17 & Gantang & 24 & 20 & 4 \\
\hline 18 & Pagak & 18 & 12 & 6 \\
\hline 19 & Pagelaran & 23 & 13 & 10 \\
\hline 20 & Pakis & 50 & 32 & 18 \\
\hline 21 & Pakisaji & 44 & 31 & 13 \\
\hline 22 & Poncokusumo & 13 & 12 & 1 \\
\hline 23 & Pujon & 20 & 16 & 4 \\
\hline 24 & Sumber Pucung & 28 & 16 & 12 \\
\hline 25 & Singosari & 56 & 42 & 14 \\
\hline 26 & $\begin{array}{c}\text { Sumber Manjing } \\
\text { Wetan }\end{array}$ & 37 & 28 & 9 \\
\hline 27 & Tajinan & 28 & 20 & 8 \\
\hline 28 & Tirtoyudho & 18 & 17 & 1 \\
\hline 29 & Tumpang & 34 & 24 & 10 \\
\hline 30 & Turen & 38 & 27 & 11 \\
\hline 31 & Wagir & 23 & 16 & 7 \\
\hline 32 & Wajak & 25 & 20 & 5 \\
\hline 33 & Wonosari & 20 & 8 & 12 \\
\hline & Total & 898 & 629 & 269 \\
\hline
\end{tabular}

Source : Dinas Koperasi dan UMKM Kabupaten Malang, 2012 


\section{Results}

Malang regent is agriculture regent with a very wide area, bordered with Blitar, Kediri, Malang city, and Pasuruan regent. Malang regent also has geographic area which is almost perfect, namely a wide plain, mountains, and seas. Malang regent has 33 districts. Based on the data from Cooperative Service and UMKM, there are 1095 cooperatives in Malang regent. The field observation result on the cooperative existence can be seen in the table 2 .

The observation results done by 12 surveyors are spread out in 33 districts in Malang regent, based on the data, there are only 898 cooperatives, with detail information that 629 are active cooperatives and 269 are non-active cooperatives. It shows that there is difference in cooperative number recorded at The Cooperative Service and UMKM Malang regent with the real condition in the field. The field observation shows 197 cooperatives recorded which do not exist in the field. To clarify the existence of 898 cooperatives in Malang regent which are spread out in every district, we can see this graph below:

\section{Classification of the Business Cooperative Kinds per District in Malang regent}

There are many kinds of cooperatives. Cooperative Business can be seen from the kinds of business like stated in the Regulation No. 251992 about cooperatives that consist of five kinds of cooperatives, namely:

\section{- Producer Cooperative}

Producer Cooperative is a cooperative whose members are the producers. The producer Cooperative members are the owner and the service users, in which in the position of producers, the cooperative members manage the materials/input to become well-done stuff/output, therefore the cooperative produces the stuffs to be traded, gets some benefits with transaction and use the market opportunity in the cooperative. The producer cooperatives play a role in supplying the raw materials, input, or the production infrastructures that support the economy members therefore the members feel the advantages of the cooperatives since the cooperatives are able to increase the business productivities of the members' business and their income.

\section{- Consumer Cooperative}

The consumer cooperative is a cooperative that does the activity for the members in order to provide the stuffs or service needed by the members. The cooperative plays a role to increase the buying power therefore the real income of the members' increases. In this cooperative, the members have identities as the owners and as a customer. In the position of the members as the consumer, the activity to consume (including consumption by the producer) is the consuming stuffs/service provided by the market. The main functions of the consumer cooperative are organizing: 1)buying or providing the stuffs/service for the members' need done efficiently, like buying something in a bigger amount and 2) the supplying innovation, like the source of the credit fund with the lower interest, some of them are revolving fund, buying stuffs with special discount, and buying something with an installment.

\section{- Credit Cooperative}

This cooperative is often put in line with the cooperative credit name, this cooperative has the deposit service and gives loans to the members. These kinds of services put the cooperative as the members' assistant to fulfill the finance service for the members to be better and better. In this cooperative, the members have double positions as owner and as customers.

In the position as a customer, a member does the saving activity and the borrowing in the form of credit/loan to the cooperative. The cooperative service to the members who save money in the form of a compulsory saving, voluntary saving and deposit, is a capital source for the cooperative. The collecting fund from the new members becomes the next capital by the cooperative to be distributed in the form of loans or credit to the members and the members to be. With the borrowing way (KSP) and/or the saving and loan business unit (USP), with those ways the cooperative does the intermedia function of the members' fund to be distributed in the form of credits to its members who need the credits. The management of saving and credit activities by the cooperative done in the form of credit and loans cooperatives.

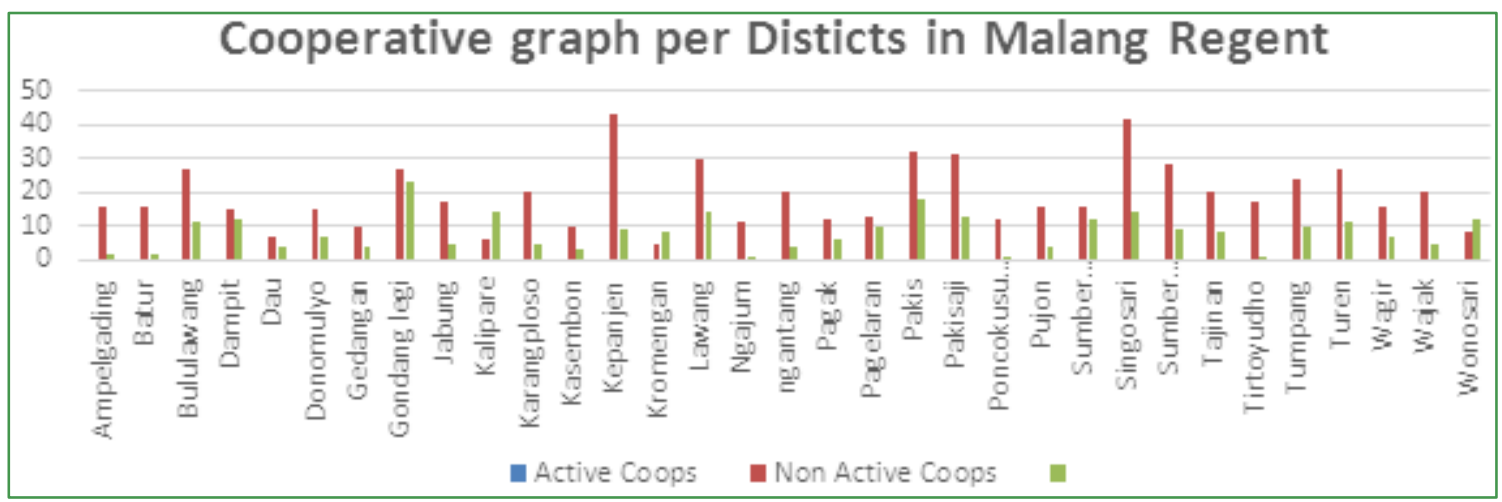

Figure 1. Cooperative Graph Per District in Malang Regent (Source : Field data) 


\section{- Business Cooperative}

Marketing cooperative is often called as a selling cooperative. The members, identities are as the owners and sellers or marketers. The marketing cooperative has function to keep the stuffs and service products produced by the members and finally market them to the customers.

The members have the positions as the stuffs suppliers or service to the cooperative. Therefore, for the members, cooperative is a front line in marketing the stuffs or service of the producer members. The success of the marketing function supports the certainty business levels for the members to remain producing.

\section{- Service Cooperative}

Service cooperative is a cooperative in which the member identities as the owner and customer of service customers and/or service producers. Whenever the members become the service consumers, the cooperative built is the service supplier cooperative. Meanwhile, whenever the members' status is as service producers, the cooperative built is the service producer cooperative or service marketing cooperative. As a service producer cooperative, the cooperative plays the functions in marketing the service produced by the producers. In practice, it is also known as dividing the cooperation based on the business management coverage (business), we call it Single purpose cooperative (one business) and Multi-Purpose (many businesses). The examples of cooperative with one business are: Credit Cooperative (KSP), Milk Producer Cooperative, Tofu and Tempe Cooperative (Primkopti). Public Credit Bank Cooperative, etc. The cooperative with more than one businesses is often called as Multi Business Cooperative. This kind of cooperative is as an example Marketing Cooperative, in which the cooperative does the marketing of the stuffs and service product.

In the cooperative practice, we know the cooperative classification, like Civil Servant Cooperative (KPN), Village Unit Cooperative (KUD), Employee Cooperative (Kopkar),
Student Cooperative (Kopma), Market Seller Cooperative, Primary Police Cooperative (Primkopol), Primary Army Cooperative (Primkopad), Primary Air Force Cooperative (Primkopau), Primary Navy Cooperative (Primkopal), etc. On the other side, the cooperatives have names like KUD Makmur, Credit Cooperative (KSP) Sejahtera, Primkopol Melati, Kopma Unpad, etc. there are also classification names cooperative like Finance Service Cooperative, Transportation Service Cooperative, Taxi Cooperative, Public Tre=ansportation Cooperative and many other cooperatives. It also happens to the Secondary Cooperatives like GKPN, PKPN, PKPRI, Batik Unit Cooperative (GKBI), Induk Koperasi Unit Desa, Pusat Koperasi Unit Desa, Puskopad, Puskopau, Puskud, etc.

Table 3. Some Active Business Cooperatives in Malang Regent

\begin{tabular}{|c|c|c|}
\hline No & The Kinds of Business Cooperative & Total \\
\hline 1 & Koperasi Jasa (Service Cooperative) & 511 \\
\hline 2 & $\begin{array}{c}\text { Koperasi Konsumen (Customer } \\
\text { Cooperative) }\end{array}$ & 21 \\
\hline 3 & Koperasi Produsen (Producer Cooperative) & 12 \\
\hline 4 & $\begin{array}{c}\text { Koperasi Serba Usaha (Business } \\
\text { Cooperative) }\end{array}$ & 85 \\
\hline & Total & $\mathbf{6 2 9}$ \\
\hline
\end{tabular}

Globally, the number of the active cooperatives spreads out in 33 districts, 629 are active cooperatives. Almost 81\% of those are service cooperative, exactly they are Credit Cooperative (KSP). Meanwhile, the customer cooperatives are only $3 \%$ (21 cooperatives), ans $13.5 \%$ rae business Cooperatives, and $2 \%$ are producer cooperatives.

This result is very ironic since Malang regent is the area of farming and agriculture, which has an amazing natural potency. It is the hard duty of the local government especially the Cooperative Service and UMKM and related institutions to support the increasing number of producer cooperative in Malang regent. Schematically, the data of the cooperative spreads can be seen in this graph below:

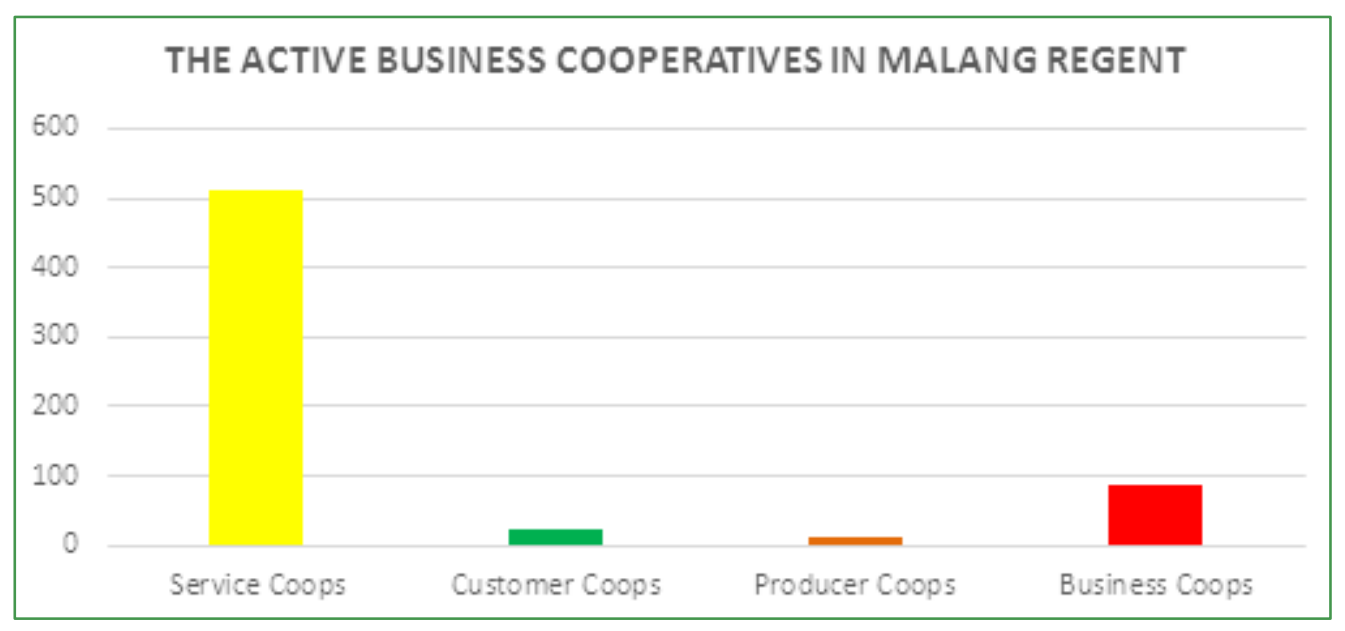

Figure 2. the active business cooperative in Malang Regent 
From the result of field observation, we get the result in which from 700 cooperative data taken from the Cooperation Service and UMKM, the active cooperatives are 220. And, from those 220, all cooperatives are credit cooperatives (Service Cooperatives), however, beside those credit cooperatives, there are 42 cooperatives of consumer cooperative, 2 cooperatives are producer ones and 8 cooperatives are business cooperative (KSU)

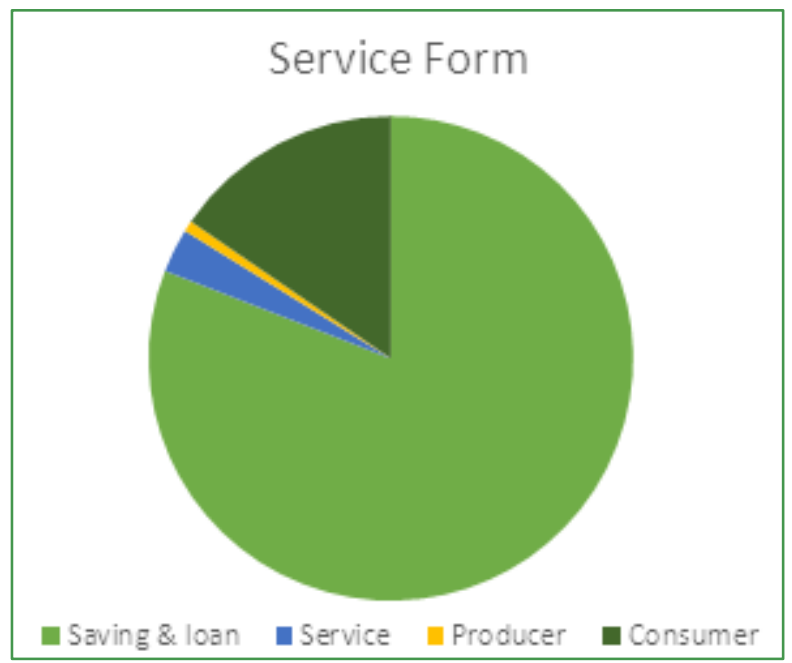

Figure 3. The Cooperative Graph in Malang regent based on the Service Form

\section{SWOT Analysis :}

- $\quad$ SO strategy (Strength-Opportunity)

a) The amount of cooperative in Malang district are very large 1095 units

b) Goodwill of East Java governor towards cooperative

c) The population of East Java enormous

d) Abundant natural resources

- WO strategy (Weakness-Opportunity)

a) Most of the cooperative in Malang districts are Simpan Pinjam (savings and loan)

b) Cooperatives are scattered in each village in Malang district

c) High competition in economic activity.

- $\quad$ ST strategy (Strength-Threat)

a) cooperative capital's assistance from government

b) geographical area is so large that there is uncontrolled in coordination.

- WT strategy (Weakness-Threat)

a) most of cooperative haven't managed by optimally and professional

b) weak cooperative capital's

c) majority of the managers of cooperatives still less educated

\section{Conclusions and Suggestions}

1. Globally, the number of the active cooperative spreads out in 33 districts with 629 active cooperatives. Almost $81 \%$ of those are service cooperatives exactly they are credit cooperative (KSP). On the other hand, consumer cooperatives are only $3 \%$ ( 21 cooperatives), and $13.5 \%$ are business coops, and $2 \%$ are producer coops. This is an ironic result since Malang regent is farming and agriculture area that has an amazing natural potency. It is the hard duty of the local government especially the Cooperative Service and UMKM and related institutions to support the increasing of producer coops in Malang regent.

2. From the field observation data done, we can get a result in which from 700 coops data gotten from the Cooperative Service only 220 are active cooperatives. Furthermore, from those 220 cooperatives, they are credit cooperatives (service coops), however; besides there are cooperatives that provide business credit, 42 coops belong to consumer cooperatives, 2 belong to producer cooperatives and 8 belong to business cooperatives (KSU).

3. The finding of SWOT analysis of cooperative existing in Malang district are SO strategy (Strength-Opportunity): the amount of cooperative in Malang district are very large 1095 units, goodwill of East Java governor towards cooperative, the population of East Java enormous and abundant natural resources. While from the point of WO strategy (Weakness-Opportunity) are most of the cooperative in Malang districts are Simpan Pinjam (savings and loan), cooperatives are scattered in each village in Malang district and high competition in economic activity. ST strategy (Strength-Threat) : cooperative capital's assistance from government and geographical area is so large that there is uncontrolled in coordination. So from WT strategy (Weakness-Threat) are most of cooperative haven't managed by optimally and professional, weak cooperative capital's and majority of the managers of cooperatives still less educated.

\section{Suggestions}

1. Improving the synergy among related institution (the Cooperative Service and UMKM), the Industry Service, the Local Government and the Education Institution) in supporting the development of the cooperatives in Regents and Malang city.

2. Giving an early learning about the roles and the functions of cooperatives to support the national development and the usefulness for the people economy movement.

3. Providing and updating the database on the existence of cooperatives in the Cooperatives Service and the local UMKM.

4. Improving the society interest towards the roles and 
the functions of producer cooperatives based on the local characteristics and the society's social, cultures, and economy.

5. The Cooperative Service and UMKM in East Java Province and Malang city should take care and update the data from the software yielded by the research

\section{REFERENCES}

[1] Bingham RD and Robert M, 1993, Theorities of Local Economic Development, London, Sage Publications.

[2] Bintarto, Metode Analisa Geografi, LP3ES, Jakarta, 1982.

[3] Blair, John P. 1995, Local Economic Development, Analysis and Practice, London, Sage Publications.

[4] Catanese, Anthony J. Catanese, James C. Snyder, Perencanaan Kota, Edisi Kedua, Erlangga, Jakarta, 1988

[5] Daldjoeni,N, Geografi Kota dan Desa, Alumni, Bandung, 1997
[6] Glasson John dalam Sitohang Paul, Pengantar Perencanaan Regional, LPFE, UI, Jakarta, 1990

[7] Hadi Sabari Yunus, Struktur Tata Ruang Kota,Pustaka Pelajar, Yogyakarta 2005

[8] Haggett, Peter, 1968, Locaional Analysis In Human Geography, London, Edward Arnold LTD

[9] Notoatmojo, Soekidjo. 1992. Pengembangan Sumber Daya Manusia. Jakarta : Rineka Cipta.

[10] Simamora, Henry. 2008. Manajemen Sumber Daya Manusia. Edisi Kedua. Yogyakarta: Penerbit STIE YKPN.

[11] Singarimbun, Masri dan Soffian Efendi. 1989. Metodologi Penelitian Survei. Jakarta : LP3ES.

[12] Steers, Richard M. 1985. Efektivitas Organisasi. Jakarta : Erlangga.

[13] The Liang Gie. 1978. Kamus Administrasi. Jakarta : PT Gunung Agung.

[14] Tulus, Moh, Agus. 1995. Manajemen Sumber Daya Manusia. Jakarta : Gramedia Pustaka Umum. 